\title{
Modulation of Fibronectin Gene Expression in Human Mononuclear Phagocytes
}

Kohei Yamauchi, Yves Martinet, and Ronald G. Crystal

Pulmonary Branch, National Heart, Lung, and Blood Institute, National Institutes of Health, Bethesda, Maryland 20892

\begin{abstract}
Under some conditions, mononuclear phagocytes spontaneously synthesize and release fibronectin, an extracellular matrix glycoprotein with versatile effects on cell-matrix interactions. To gain insight into the processes that modulate the level of fibronectin secretion by these cells, we used monocytes, in vitro matured monocytes and alveolar macrophages as models to compare fibronectin mRNA levels and fibronectin secretion in a variety of circumstances. Using Northern analysis and dot-blot analysis with a ${ }^{32} \mathbf{P}$-labeled human fibronectin cDNA probe, we evaluated steady-state mRNA levels and a human fibronectin-specific ELISA was used to evaluate fibronectin secretion. In all cases the amounts of fibronectin secreted paralleled fibronectin mRNA levels. Specifically $(a)$ when fibronectin mRNA was undetectable, as in the case of normal blood monocytes, no fibronectin was secreted, but whenever fibronectin mRNA was present, as in normal alveolar macrophages, fibronectin was secreted by the cells; $(b)$ as monocytes matured into macrophages in vitro, the cells began to express fibronectin mRNA and the cells secreted fibronectin; (c) when alveolar macrophages were activated with surface stimuli such as lipopolysaccharide (LPS) or immune complexes, fibronectin mRNA levels decreased and in parallel, the cells secreted less fibronectin; $(d)$ in idiopathic pulmonary fibrosis (IPF), alveolar macrophages contained severalfold more fibronectin mRNA transcripts that normal and the cells spontaneously secreted severalfold more fibronectin than normal; and (e) when IPF alveolar macrophages were placed in culture the fibronectin mRNA levels in the cells decreased with time, and concurrently the amounts of fibronectin produced per unit time continually decreased. The observation of a strict concordance of fibronectin mRNA levels and fibronectin release by mononuclear phagocytes suggests that, at least in many circumstances, fibronectin secretion by mononuclear phagocytes is controlled by steady-state levels of fibronectin mRNA.
\end{abstract}

\section{Introduction}

Fibronectin is a 440,000-D dimeric glycoprotein produced by a variety of cells and capable of functioning in a broad range of biologic processes including cell adhesion, spreading, cytoskeletal organization, migration, proliferation, and differentiation (1-5). Fibronectin accomplishes these diverse processes by acting as a ligand between cells and macromolecules through the use of structural domains in the fibronectin molecule with

Address reprint requests to R. Crystal, Building 10, Room 6D03, Pulmonary Branch, National Institutes of Health, Bethesda, MD 20892.

Received for publication 11 February 1987 and in revised form 20 May 1987.

The Journal of Clinical Investigation, Inc.

Volume 80, December 1987, 1720-1727 affinity for collagen, heparin, fibrin, DNA, and cell surfaces (1-5).

One source of fibronectin is the alveolar macrophage, a bone marrow-derived mononuclear phagocyte that plays a major role in inflammatory processes in the lower respiratory tract in health and disease (6-8). Several studies have demonstrated that alveolar macrophages synthesize and secrete fibronectin and that alveolar macrophages associated with chronic inflammatory diseases of the lower respiratory tract secrete exaggerated amounts of this molecule (6-8). In the context of the known functions of fibronectin, it is likely that it represents one of the alveolar macrophage mediators that plays a role in both defending the lung and in modulating the damage and repair that accompanies inflammatory processes in the lower respiratory tract (6-14).

With this background, the present study was designed to evaluate the level at which production of fibronectin by human mononuclear phagocytes is modulated. To accomplish this, we have quantified fibronectin mRNA levels and fibronectin secretion in these cells under a variety of conditions, including circumstances where fibronectin secretion appears to be undetectable, up-regulated, and down-regulated. The data obtained are consistent with the concept that, in many situations, fibronectin secretion by these cells is regulated by steady-state fibronectin mRNA levels.

\section{Methods}

Study population. The normal population consisted of 10 nonsmoking individuals (seven males, three females; mean age, $33 \pm 2$ yr [all data are presented as mean $\pm \mathrm{SE}$; all statistical comparisons are made using the two-tailed Student's $t$ test]) with no history of lung disease. All had normal lung function tests and chest $x$ rays. None were taking medications. The "fibrotic" lung disorder, idiopathic pulmonary fibrosis (IPF), ${ }^{1}$ was used as an example of a chronic inflammatory lung disorder in which it is known that alveolar macrophages are producing elevated levels of fibronectin (7). This population consisted of 19 individuals ( 11 males, 8 females; mean age, $54 \pm 3 \mathrm{yr}$ ) in whom the diagnosis of IPF was made using established criteria, including open lung biopsy (15). All patients were in mid-course of their disease (16). Of the 19,11 were taking no medications and 8 were taking prednisone at the time of evaluation. Nine were lifelong nonsmokers and 10 had a history of cigarette smoking but had discontinued smoking at least $3 \mathrm{yr}$ before evaluation. As a group, the patients with IPF had the following functional abnormalities (15): vital capacity, $52 \pm 3 \%$ predicted; total lung capacity, $57 \pm 3 \%$ predicted; forced expiratory volume in $1 \mathrm{~s} /$ forced vital capacity, $113 \pm 3 \%$ predicted; and single-breath diffusion capacity (corrected for volume and hemoglobin), $49 \pm 4 \%$ predicted.

Source of mononuclear phagocytes. Monocytes were prepared from blood mononuclear cells of normal individuals obtained by Ficoll-Hypaque centrifugation (17). Monocytes were purified from the mononuclear cell layer by adherence to a plastic dish in $\operatorname{DME}\left(1 \mathrm{~h}, 37^{\circ}\right)$. In all cases, the monocyte populations were $>\mathbf{8 0 \%}$ pure as assessed by mor-

1. Abbreviation used in this paper: IPF, idiopathic pulmonary fibrosis. 
phology after staining with Diff-Quik (American Scientific Products, McGaw Park, IL) and nonspecific esterase (18) and were >99\% viable as estimated by trypan blue exclusion.

Alveolar macrophages were obtained by bronchoalveolar lavage of normals and individuals with IPF using $0.9 \%$ saline as previously described (19). Bronchoalveolar lavage cell differentials (determined by filter preparations) for the normals included macrophages, $86 \pm 1 \%$, lymphocytes, $10 \pm 1 \%$, neutrophils, $1 \pm 1 \%$ and eosinophils, $1 \pm 1 \%$, and for the IPF patients included macrophages, $84 \pm 3 \%$, lymphocytes, $6 \pm 1 \%$, neutrophils, $7 \pm 2 \%$, and eosinophils, $3 \pm 4 \%$. The viability of the alveolar macrophages as assessed by trypan blue exclusion was $>90 \%$ in all cases.

Quantification of fibronectin secreted by mononuclear phagocytes. To measure the amount of fibronectin secreted by the mononuclear phagocytes in various conditions, the cells were cultured without serum in DMEM (alone or with additions as specifically noted below) at $37^{\circ}$. All cultures for collection of supernatants for fibronectin measurement were for $24 \mathrm{~h}$ unless noted otherwise. The supernatants were collected, clarified by centrifugation $(10,000 \mathrm{~g}, 10 \mathrm{~min})$ and stored at $-20^{\circ}$. All measurements were carried out by a human fibronectin-specific ELISA as previously described (20).

Evaluation of fibronectin mRNA. Cellular RNA was extracted by the guanidine isothiocyanate method (21). The cells were lysed as a pellet or as a monolayer on tissue culture plates in $4 \mathrm{M}$ guanidine isothiocyanate solution. The lysates were shaken vigorously, mixed with cesium chloride $(1 \mathrm{~g} / 2.5 \mathrm{ml})$ layered on a cushion of $5.7 \mathrm{M}$ cesium chloride, 0.1 M EDTA, pH 7.6, in a polyallomer tube (Beckman Instruments, Inc., Fullerton, CA) and centrifuged at $20^{\circ} \mathrm{C}$ in an SW60 rotor (Beckman Instruments, Inc., 35,000 rpm, $12 \mathrm{~h}$ ). The pellet was dissolved in $100 \mathrm{mM} \mathrm{NaCl}, 10 \mathrm{mM}$ Tris- $\mathrm{HCl}, \mathrm{pH} 8.6,1 \mathrm{mM}$ EDTA, $1 \%(\mathrm{wt} / \mathrm{vol})$ SDS, precipitated with ethanol, redissolved in water, and stored in liquid nitrogen vapor.

Fibronectin mRNA in the cellular RNA extracts was evaluated using Northern analysis in a $1 \%$ agarose gel under denaturing conditions. Transfer to nitrocellulose filter (BA85, Schleicher \& Schuell, Keene, $\mathrm{NH}$ ) was performed according to Thomas (22). Fibronectin mRNA was detected by using human fibronectin cDNA (FN421; kindly provided by M.-L. Chu, University of Medicine and Dentistry of New Jersey-Robert Wood Johnson Medical School) (23). As a control, $\gamma$-actin mRNA in the samples was evaluated using a human fibroblast cytoplasmic $\gamma$-actin cDNA (plasmid pHF A-1; kindly provided by $\mathrm{P}$. Gunning and L. Kedes, Stanford University) (24). ${ }^{32} \mathrm{P}$-Labeled Hind III fragments of $\lambda$ DNA were used as radioactive size markers.

Quantification of fibronectin in the cellular RNA extracts was carried out by dot-blot analysis (25). Total RNA $(10 \mu \mathrm{g})$ was dissolved in a solution of $6.15 \mathrm{M}$ formaldehyde $/ 10 \times \mathrm{SSC}(1 \times \mathrm{SSC}=150 \mathrm{mM} \mathrm{NaCl}$, $15 \mathrm{mM} \mathrm{Na}$ citrate, $\mathrm{pH} \mathrm{7.0)}$ and was heated at $56^{\circ}$ for $15 \mathrm{~min}$. Denatured RNA ( $5 \mu \mathrm{g} / \mathrm{dot}$ for the initial dot, with subsequent twofold dilutions) were applied to nitrocellulose filter paper (Schleicher \& Schuell) using a manifold apparatus (Schleicher \& Schuell). Total RNA content of each serially diluted sample was maintained at $5 \mu \mathrm{g} /$ sample by adding yeast tRNA (Bethesda Research Laboratories, Gaithersburg, MD). After baking $\left(2 \mathrm{~h}, 80^{\circ}\right)$ the nitrocellulose filter paper was hybridized using the ${ }^{32} \mathrm{P}$-labeled fibronectin cDNA probe. Fibronectin mRNA from fetal lung fibroblasts (HFL-1; ATCC CCL153) was used as a standard. Arbitrarily, $2.5 \mu \mathrm{g}$ of total fibroblast RNA was defined as containing $1 \mathrm{U}$ fibronectin mRNA. As a control for studies evaluating fibronectin mRNA levels following activation of normal alveolar macrophages, interleukin- $1 \beta$ mRNA levels were quantified using a human interleukin- $1 \beta$ cDNA probe (26). As a control for studies evaluating the time-dependent changes in fibronectin mRNA levels during in vitro culture of IPF alveolar macrophages, apolipoprotein E mRNA levels were quantified using an apolipoprotein E cDNA probe (kindly provided by S. W. Law and H. B. Brewer, Molecular Disease Branch, National Heart, Lung and Blood Institute) (27). All probes were labeled by nick translation using $\left[{ }^{32} \mathrm{P}\right] \mathrm{dCTP}(3,000 \mathrm{Ci} / \mathrm{mmol}$; Amersham Corp., Arlington Heights, IL) and the labeled cDNA was purified using
NACS Prepac (Bethesda Research Laboratories). This procedure always yielded labeled probes with sp act $>2 \times 10^{8} \mathrm{dpm} / \mu \mathrm{g}$ DNA. Hybridization, washing conditions, and autoradiograms were carried out as described by Meinkoth and Wahl (28) with minor modifications (29). Briefly, hybridization was carried out at $40^{\circ}, 18 \mathrm{~h}$ followed by washing of the filters four times $\left(25^{\circ}, 5 \mathrm{~min}\right.$ each) in $2 \times \mathrm{SSC} 0.05 \%$ disodium pyrophosphate and four times $\left(60^{\circ}, 30 \mathrm{~min}\right.$ each) in 0.1 $\times$ SSC, $0.05 \%$ disodium pyrophosphate. Autoradiograms were performed using an intensifying screen at $-80^{\circ}$. All data were expressed as mRNA units per $10^{6}$ mononuclear phagocytes. The number of fresh cells was determined by direct counting and in cultured cells by collecting cells from parallel plates after treatment with Hanks' balanced salt solution $\left(\mathrm{Ca}^{2+}\right.$ and $\mathrm{Mg}^{2+}$ free) $2.5 \mathrm{mM}$ EDTA $\left(4^{\circ}, 20 \mathrm{~min}\right)$ and scraping with a rubber policeman. All cell counts were performed by hemocytometer.

Evaluation of fibronectin $m R N A$ levels and fibronectin secretion under various conditions. Five different circumstances were used to compare the amounts of fibronectin mRNA levels with fibronectin secretion.

First, fresh normal blood monocytes and fresh alveolar macrophages were evaluated. Fibronectin mRNA levels were determined in the monocytes and alveolar macrophages from the same individuals immediately after cell purification. To quantify fibronectin secretion, monocytes and alveolar macrophages were cultured in parallel (DME, $24 \mathrm{~h}, 37^{\circ}, 10 \mathrm{~cm}$ diameter petri dish, Falcon Labware, Becton Dickinson \& Co., Oxnard, CA), and the supernatants were collected and analyzed for fibronectin.

Second, these parameters were quantified during the maturation of monocytes to macrophages in culture. To accomplish this, monocytes were cultured from 1 to $14 \mathrm{~d}\left(4 \times 10^{7}\right.$ monocytes/plate; $10 \mathrm{~cm}$ diameter petri dish) in DME, $10 \%$ heat-inactivated fetal bovine serum (Gibco, Grand Island, NY), and $50 \mu \mathrm{g} / \mathrm{ml}$ gentamycin. The medium was changed every $3 \mathrm{~d}$. Fibronectin mRNA levels were determined at various time points and in parallel cultures the secretion of fibronectin was evaluated by removing the old culture media and culturing cells in fresh serum-free medium over a 24-h period.

Third, based on the knowledge that alveolar macrophages from patients with IPF secrete severalfold higher amounts of fibronectin than normal alveolar macrophages (7), fibronectin mRNA levels and secretion were compared in alveolar macrophages from normals and patients with IPF. The mRNA levels were evaluated in the cells immediately after lavage. For evaluation of fibronectin secretion, the cells recovered by lavage were cultured in DME $\left(1 \times 10^{7}\right.$ macrophages/ plate) without serum for $1 \mathrm{~h}, 37^{\circ}$. The nonadherent cells were removed by vigorous washing, fresh medium was added, the cells were incubated for $24 \mathrm{~h}$, and the supernatants were collected.

Fourth, normal alveolar macrophages were evaluated after activation. Alveolar macrophages from normal individuals were divided into three groups: cultured in serum-free DME alone, with the addition of lipopolysaccharide (LPS, Escherichia coli 0127; B8, Difco Laboratories Inc., Detroit, MI; $10 \mu \mathrm{g} / \mathrm{ml}$ ), or immune complexes (human albumin and rabbit anti-human albumin, Cappel Laboratories, Cochranville, PA; final protein concentration of $10 \mu \mathrm{g} / \mathrm{ml}$ ) (30). All cultures were with $1 \times 10^{7}$ cells/plate $\left(37^{\circ}, 24 \mathrm{~h}\right)$. At the end of this time, RNA was extracted from the adherent cells and the supernatant was recovered for measurement of fibronectin secretion. As a control for the fibronectin mRNA levels, the same RNA samples were used to quantify interleukin- $1 \beta$ mRNA levels.

Fifth, alveolar macrophages from individuals with IPF were cultured for varying periods up to $24 \mathrm{~h}$ to evaluate whether the up-regulation of mRNA levels and fibronectin secretion observed in these cells was maintained. To accomplish this, alveolar macrophages recovered by lavage from IPF patients were purified by adherence as described above. Fresh medium (DME without serum) was added, and the culture continued for $4,8,12$, or $24 \mathrm{~h}$. Fibronectin mRNA levels were evaluated in fresh macrophages (after the adherence step) and after 24 $h$ in culture. As a control, the same RNA samples were used to quantify apolipoprotein E mRNA levels. Supernatants from the cultures 
A

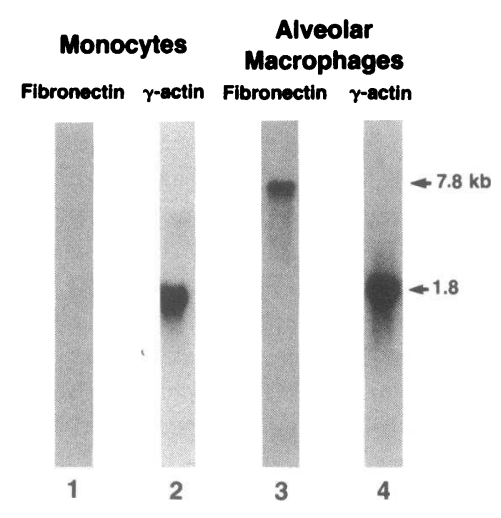

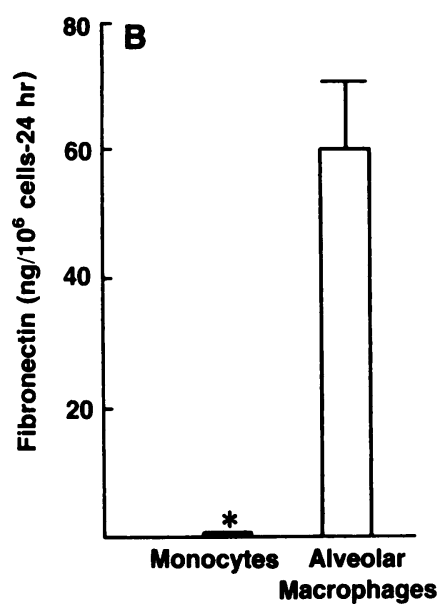

Figure 1. Spontaneous expression of fibronectin mRNA and secretion of fibronectin by blood monocytes and alveolar macrophages. $(A)$ Presence of fibronectin mRNA transcripts in normal blood monocytes and alveolar macrophages. RNA extracted from the cells was electrophoresed in agarose (10 $\mu \mathrm{g} /$ lane), transferred to nitrocellulose filter by the Northern method, and evaluated using a ${ }^{32} \mathrm{P}$-labeled fibronectin cDNA probe (lanes $l$ and 3 ) or a ${ }^{32} \mathrm{P}$-labeled $\gamma$-actin cDNA probe (lanes 2 and 4 ). The sizes of the fibronectin and $\gamma$-actin mRNA transcripts were determined using DNA markers (see Methods). (B) Secretion of fibronectin by normal monocytes and alveolar macrophages. The cells were cultured in DME without serum for $24 \mathrm{~h}$ and the supernatants evaluated for the presence of fibronectin by ELISA. *Undetectable. were evaluated for fibronectin levels every $4 \mathrm{~h}$ for up to $12 \mathrm{~h}$ and then over the subsequent $12 \mathrm{~h}$.

\section{Results}

Spontaneous fibronectin gene expression by normal blood monocytes and alveolar macrophages. There was a marked difference in fibronectin mRNA levels in normal blood monocytes and normal alveolar macrophages (Fig. $1 A$ ). In all cases, Northern analysis of RNA extracted from normal monocytes and alveolar macrophages demonstrated that blood monocytes did not contain any fibronectin mRNA, whereas alveolar macrophages spontaneously expressed a 7.8-kb fibronectin specific mRNA. In contrast to the difference in fibronectin mRNA levels between the two cell types, evaluation of the same RNA samples demonstrated that the $\gamma$-actin gene was expressed by both blood monocytes and alveolar macrophages. This difference in fibronectin mRNA levels was paralleled by a difference in fibronectin secretion by these cells. Whereas normal blood monocytes did not release any detectable amount of fibronectin, normal alveolar macrophages spontaneously released large amounts of fibronectin (Fig. $1 B$ ).

Fibronectin gene expression during monocyte maturation. Because alveolar macrophages, a differentiated form of monocytes, spontaneously expressed the fibronectin gene whereas blood monocytes did not, it is reasonable to hypothesize that the maturation process is accompanied by the spontaneous expression of this gene. To evaluate this hypothesis, blood monocytes were cultured in vitro and allowed to mature over a period of $14 \mathrm{~d}$, and expression of the fibronectin gene was evaluated. Consistent with the hypothesis, as monocytes matured in vitro, they began to demonstrate fibronectin mRNA transcripts and these levels increased with time (Fig. $2 \mathrm{~A}$ ). In this experiment, the RNA/cell ratio increased during in vitro maturation of blood monocytes (fresh monocytes RNA $/ 10^{6}$ cells $0.5 \pm 0.1 ; 1$-d cultured monocytes, $0.6 \pm 0.1 ; 3 \mathrm{~d}, 0.8 \pm 0.2 ; 7$ d, $5.5 \pm 0.8$; and $14 \mathrm{~d}, 8.9 \pm 1.3$ ). In addition, the specific proportion of fibronectin mRNA among the total RNA also increased significantly (fresh monocytes and 1-d cultured monocytes had no fibronectin mRNA, 3-d monocytes, $0.035 \pm 0.004$ fibronectin mRNA U/5 $\mu \mathrm{g}$ total RNA, $7 \mathrm{~d}, 0.191 \pm 0.005$; and $14 \mathrm{~d}, 0.363 \pm 0.023$ ). Evaluation of the size of these transcripts by Northern analysis demonstrated they were $7.8 \mathrm{~kb}$, similar to those of normal alveolar macrophages (not shown). Furthermore, the increasing levels of fibronectin mRNA were paralleled by the amounts secreted per $24 \mathrm{~h}$ increasing with time in culture (Fig. $2 B$ ).

Modulation of fibronectin gene expression by alveolar macrophages by surface activation. Because LPS and immune complexes are capable of activating mononuclear phagocytes
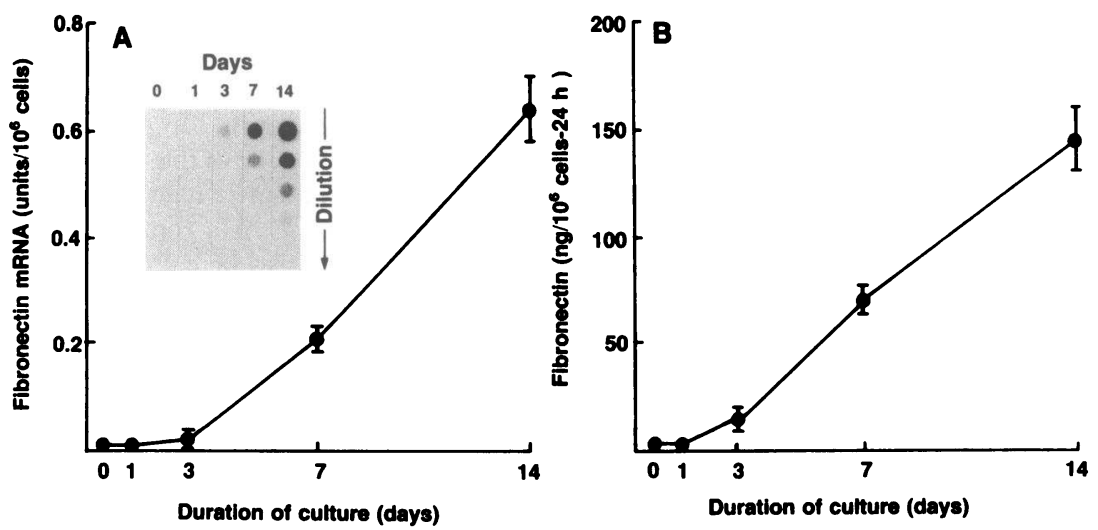

Figure 2. Expression of fibronectin mRNA and secretion of fibronectin by in vitro matured blood monocytes. Normal blood monocytes were cultured in DME with serum for 0-14 d. At various times, as indicated, serum was removed, the cells rinsed, and cultures continued in DME for an additional 24 h. (A) Quantification of fibronectin mRNA levels in in vitro matured monocytes. RNA was extracted from the cells evaluated in $A$ and fibronectin mRNA levels measured using dot-blot analysis and a ${ }^{32} \mathrm{P}$-labeled fibronectin cDNA probe. For each time point, the initial "dot" contained $5 \mu \mathrm{g}$ RNA and subsequent dots contained sequential twofold dilutions. The autoradiograms of the dots were quantified using densitometry and the data expressed as mRNA units per $10^{6}$ cells using measurements of RNA per cell made in parallel plates. (Inset) An example of dot-blot analysis from cells at various times in culture. $(B)$ Secretion of fibronectin by in vitro matured monocytes. The supernatant fluid was collected over the last $24 \mathrm{~h}$ of culture and assessed for fibronectin by ELISA. 
through surface receptors to up-regulate a variety of secreted mediators, it was reasonable to expect that LPS and/or immune complexes would up-regulate fibronectin gene expression as well. However, neither LPS nor immune complexes were capable of stimulating normal blood monocytes to express fibronectin mRNA levels or to secrete fibronectin (data not shown). Furthermore, unexpectedly, the addition of LPS or immune complexes to alveolar macrophages was followed by a decrease in fibronectin mRNA levels (Fig. $3 A$ ). However, Northern analysis demonstrated that the form of the fibronectin mRNA was similar to that found in fresh cells, i.e., $7.8 \mathrm{~kb}$ (not shown). This was not a result of a general down-regulation of gene expression. Both stimuli caused the alveolar macrophages to increase interleukin- $1 \beta$ gene expression (Fig. $3 \mathrm{~B}$ ) and of interleukin-1 release (data not shown). Furthermore, the apparent down-regulation of fibronectin mRNA levels was paralleled by a decrease in the spontaneous release of fibronectin (LPS, $60 \pm 3 \%$ of control; immune complexes, $57 \pm 5 \%$ of control; $P<0.01$, both comparisons, Fig. $3 C$ ), i.e., the addition of LPS or immune complexes reduced fibronectin mRNA levels and fibronectin secreted by the normal alveolar macrophages (Fig. 3, $A$ and $C$ ). In marked contrast, both stimuli caused the alveolar macrophages to increase interleukin- $1 \beta$ gene expression (Fig. $3 B$ ) and of interleukin-1 release (data not shown).

Exaggerated fibronectin gene expression by alveolar macrophages from patients with IPF. Quantification of fibronectin mRNA levels by dot-blot analysis demonstrated that the level of fibronectin mRNA in alveolar macrophages from patients with IPF was eightfold higher than in normals (Fig. $4 \mathrm{~A} ; \mathrm{P}$ $<0.01$ ). Northern analysis showed that the size of fibronectin mRNA in the IPF alveolar macrophages was similar to that in normal alveolar macrophages (not shown). No differences were observed in fibronectin mRNA levels among ex-smokers and among individuals not treated or those treated. In parallel with this observation, as previously shown, alveolar macrophages from patients with IPF spontaneously secreted more fibronectin than normal alveolar macrophages (7). In this regard, alveolar macrophages from patients with IPF secreted eightfold more fibronectin than normals (Fig. $4 B ; P<0.01$ ), i.e., alveolar macrophages from these individuals appeared to have up-regulated the fibronectin gene.

Time-dependent change of fibronectin gene expression by alveolar macrophages from patients with IPF maintained in culture. Because alveolar macrophages of IPF patients appear to have up-regulated the fibronectin gene compared with normals, we asked whether this exaggerated fibronectin gene expression was a constitutive property of these cells. To answer this question, alveolar macrophages from patients with IPF were cultured in serum-free DME and fibronectin mRNA levels and fibronectin secretion evaluated over time (Fig. 5). This levels of fibronectin mRNA in these alveolar macrophages after $24 \mathrm{~h}$ in culture was reduced to one-third of the original level $(P<0.01$; Fig. $5 A)$. However, Northern analysis showed the size of the fibronectin mRNA transcripts were 7.8 $\mathrm{kb}$, same as normal (not shown). This change was not a non-

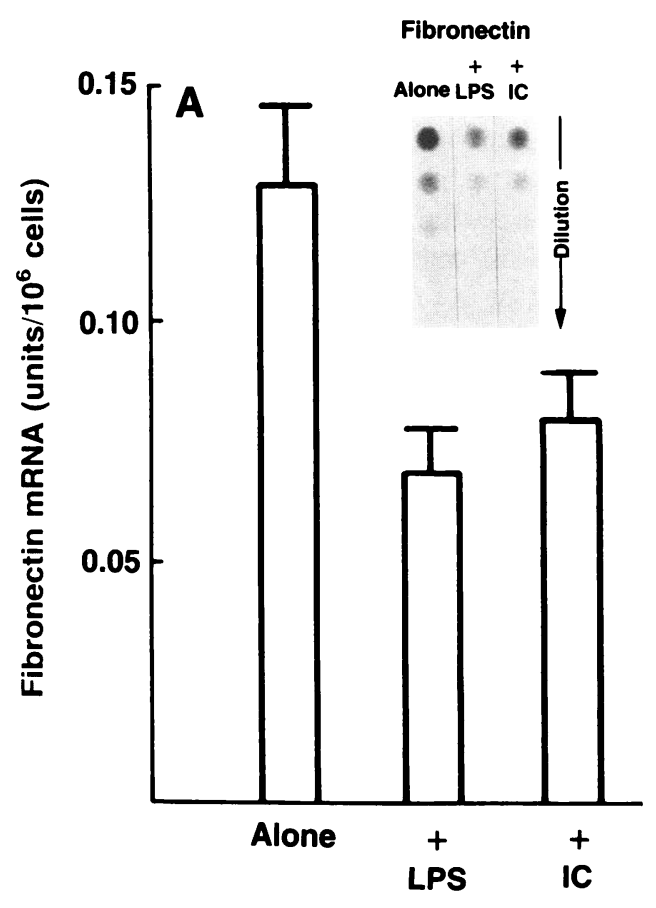

Figure 3. Effect of surface membrane stimulation on the expression of fibronectin mRNA transcripts and secretion of fibronectin by alveolar macrophages. Normal alveolar macrophages were incubated in DME alone or in the presence of LPS $(10 \mu \mathrm{g} / \mathrm{ml})$ or IgG immune complexes $(I C ; 10 \mu \mathrm{g} / \mathrm{ml})$ for $24 \mathrm{~h}$. (A) Quantification of fibronectin mRNA levels by dot-blot analysis. The RNA was extracted and fibronectin mRNA levels were measured as for Fig. 2. Each initial dot contained $5 \mu \mathrm{g}$ RNA. (Inset) Example of the dot-blot analysis under
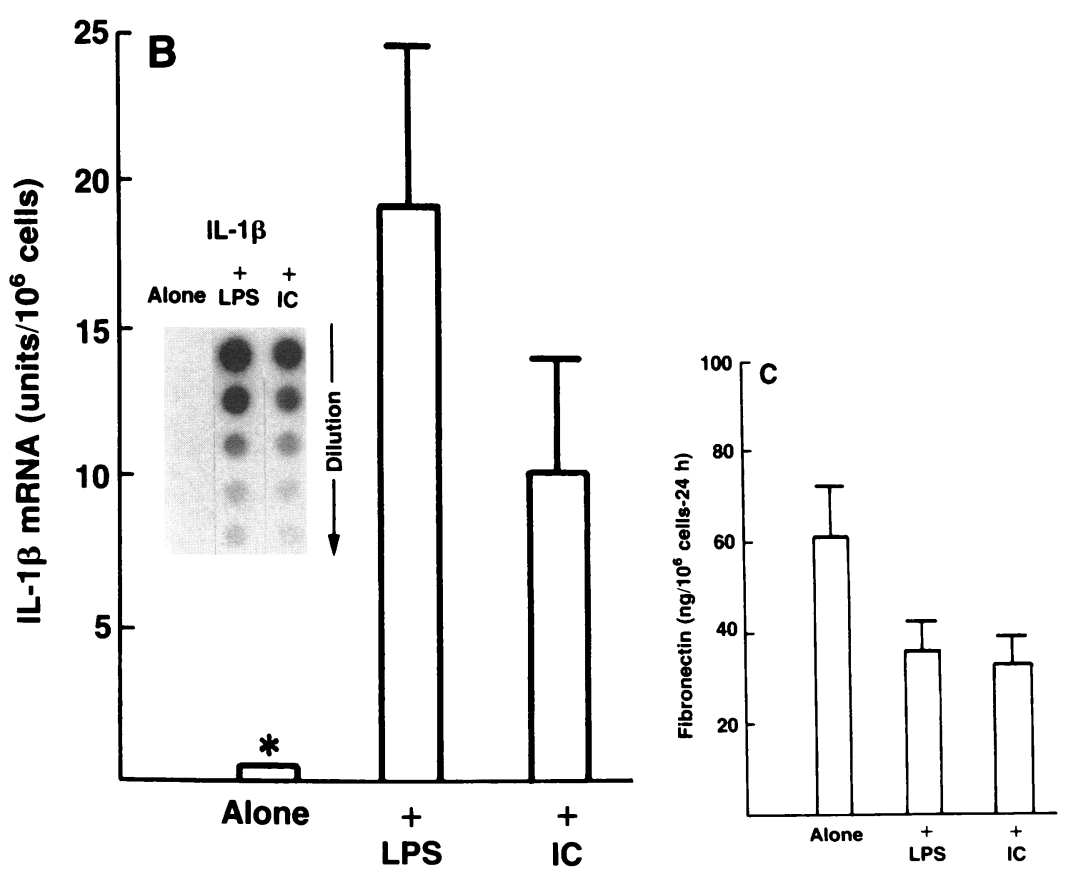

the various conditions. $(B)$ Quantification of interleukin-1 $\beta(I L-1 \beta)$ mRNA levels. As a control, the same RNA samples analyzed in $B$ were also evaluated for IL-1 $\beta$ mRNA levels. (Inset) Example of the dot-blot analysis under the various conditions. ${ }^{*} I L-1 \beta$ mRNA levels were undetectable with the exposure used; with very long exposures, a small amount of IL- $1 \beta$ mRNA could be detected in unstimulated alveolar macrophages. $(C)$ Secretion of fibronectin into the media as assessed by ELISA. 

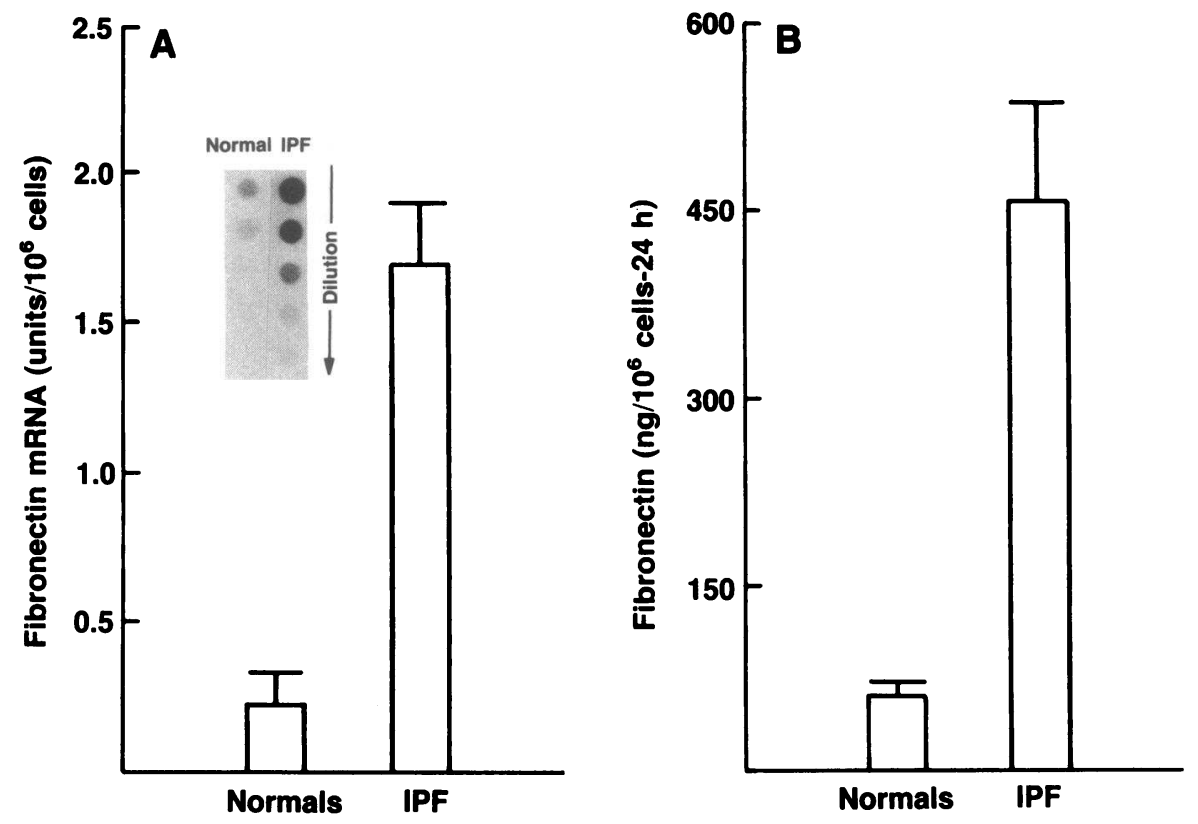

Figure 4. Spontaneous expression of fibronectin mRNA transcripts and secretion of fibronectin by normal alveolar macrophages and alveolar macrophages from individuals with idiopathic pulmonary fibrosis $(I P F)$. (A) Quantification of fibronectin mRNA levels in alveolar macrophages freshly obtained from normals and individuals with IPF. RNA was extracted and fibronectin mRNA levels were quantified using dot-blot analysis as described in Fig. $2(5 \mu \mathrm{g} /$ initial dot). (Inset) Example of the dot-blot analysis. (B) Alveolar macrophages were cultured in DME for $24 \mathrm{~h}$ and fibronectin in the supernatants quantified by ELISA.

specific effect due to the culture conditions because the same alveolar macrophages contained apolipoprotein E mRNA levels that were identical at the same time points $(P>0.2$; Fig. $5 B$ ). In addition, the ApoE mRNA amount per cell in normal alveolar macrophages did not change significantly during $24 \mathrm{~h}$ culture in serum-free DME ( $P>0.1$; data not shown). Consistent with this time-dependent decrease in fibronectin mRNA levels, the spontaneous release of fibronectin by the cultured IPF alveolar macrophages decreased in a time-dependent manner (initial collection of $0-4 \mathrm{~h} 14.9 \pm 1.9 \mathrm{ng} / 10^{6}$ cells-h vs. final collection of $12-24$ h $5.5 \pm 1.0 \mathrm{ng} / 10^{6}$ cells-h; $P<0.01$; Fig. 5 C).

\section{Discussion}

Fibronectin is a major body constituent, present as a component of most extracellular matrices and in plasma at levels of
$300 \mu \mathrm{g} / \mathrm{ml}(1-5,31,32)$. Fibronectin is a multifunctional protein, and there is a broad spectrum of in vitro and in vivo studies implicating fibronectin in cell attachment, differentiation, and proliferation (1-5). There are many sources of fibronectin, including fibroblasts, epithelial cells, chondrocytes, myoblasts, amniotic cells, endothelial cells, hepatocytes, and mononuclear phagocytes (1-8, 33-38). Among these, mononuclear phagocytes are the one example of a class of fibronectin producing cells that are mobile (39). In this regard, mononuclear phagocytes are derived from a common bone marrow precursor, circulate in blood, and move into tissues where they serve to defend internal organs (39). Furthermore, mononuclear phagocytes play a central role in inflammatory states, where the numbers of these cells accumulate at sites of injury $(40,41)$. In the context of the many roles of fibronectin, the mononuclear phagocytes likely provide one mechanism to deposit fibronectin at sites where it may be used in both normal
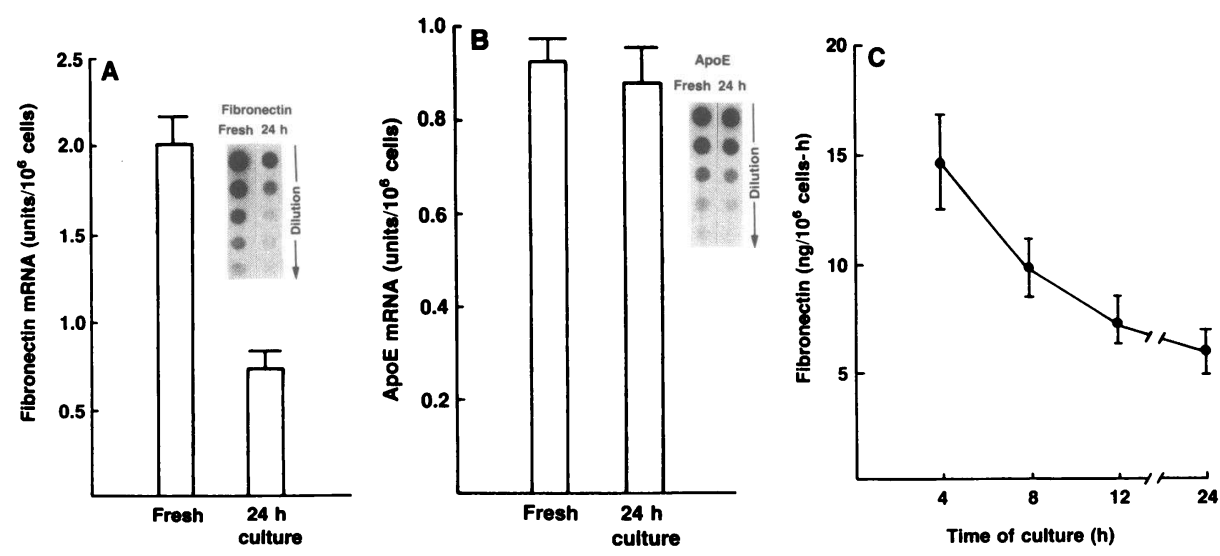

Figure 5. Time-dependent changes in fibronectin mRNA levels and fibronectin secretion by cultured alveolar macrophages of individuals with idiopathic pulmonary fibrosis (IPF). Alveolar macrophages of individuals with IPF were cultured $24 \mathrm{~h}$ in DME $\left(10^{6}\right.$ cells/ $\mathrm{ml})$ and fibronectin mRNA levels and the amount of fibronectin secreted determined at various times. (A) Fibronectin mRNA levels when the alveolar macrophages were fresh compared with after $24 \mathrm{~h}$ in culture. RNA was extracted from the cells at 0 time and at $24 \mathrm{~h}$ and the fibronectin mRNA levels quantified by dot-blot analysis as in Fig. $2(5 \mu \mathrm{g} /$ initial dot). (Inset) Example of the dot-blot analysis. (B) Quantification of apolipoprotein E (ApoE) mRNA levels. As a control, mRNA levels of another macrophage secreted protein, ApoE, were quantified in the same RNA samples analyzed in $A$. (Inset) Example of the dot-blot analysis. (C) Secretion of fibronectin over various time intervals in culture. The supernatants were evaluated every $4 \mathrm{~h}$ for up to $12 \mathrm{~h}$ and then over the subsequent $12 \mathrm{~h}$. Fibronectin levels in the supernatant were quantified by ELISA and expressed as fibronectin secreted per hour over the respective time intervals. 
body functions as well as playing a role in repair processes following injury.

Fibronectin is produced and handled by fibronectin synthesizing cells as a typical secretory glycoprotein. The fibronectin gene consists of at least 50 exons (42). There is one fibronectin gene per parental genome $(43,44)$. Using blood monocytes, in vitro matured macrophages, normal alveolar macrophages, and alveolar macrophages recovered from individuals with the chronic inflammatory lung disease, the present study demonstrates that the amounts of fibronectin secreted could be related to the levels of fibronectin mRNA within the population of cells evaluated. The mechanism of this increase is unknown. Measurement of transcriptional rate of fibronectin mRNA in mononuclear phagocytes would give insight into the processes modulating the fibronectin mRNA levels. Unfortunately, because of the relatively small number of normal alveolar macrophages obtained by bronchoalveolar lavage, such measurements are not possible.

In all mononuclear phagocyte populations evaluated in the present study, Northern analysis demonstrated fibronectin transcripts of $\sim 7.8 \mathrm{~kb}$ in length. However, analysis of fibronectin mRNA by Northern analysis cannot detect the minor variations in fibronectin mRNA size resulting from alternative splicing $(42,44-57)$. Whereas such variations appear to relate, at least in part, to cell specificities producing the fibronectin $(48,53)$, it is not known if the process of alternative splicing relates in any fashion to modulating fibronectin mRNA levels for a given cell.

Despite the extensive study of the structure and function of fibronectin at the protein level and the structure of fibronectin at the gene level, little is known about the levels at which cells modulate the expression of this gene. Presumably, the variable levels of fibronectin mRNA observed in the various circumstances evaluated in the present study are modulated at the level of fibronectin gene transcription. For example, Raghow et al. (58) have recently observed that in the lungs of bleomycin-treated hamsters, the rate of nuclear transcription of the fibronectin gene paralleled the temporal changes in steadystate fibronectin mRNA levels. Likewise, the decreased fibronectin mRNA levels observed with transformation of embryo fibroblasts by the Rous sarcoma virus are thought to result from decreased transcription and not changes in fibronectin mRNA stability (59). However, we have only evaluated steady-state mRNA levels. Furthermore, no information is available at this time regarding the structure and/or function of the controlling elements for fibronectin gene expression, nor of the mechanisms modulating the fibronectin mRNA lifespan.

Besides the general observation of the correlation of fibronectin mRNA levels and fibronectin secretion by mononuclear phagocytes, two phenomena observed in the expression of the fibronectin gene by these cells were striking. First, despite the fact that stimuli like LPS and immune complexes up-regulate the production of many mediators by mononuclear phagocytes $(60,61)$, these stimuli were incapable of stimulating monocytes to express this gene or of stimulating alveolar macrophages to up-regulate the fibronectin gene. Second, alveolar macrophages from individuals with IPF appear to have markedly up-regulated fibronectin genes. However, when placed in culture, this up-regulation was rapidly lost. Because this occurred while the expression of genes coding for other secretory proteins like apolipoprotein E remained constant, this suggests that either the in vivo stimulus had been lost (i.e., and hence the in vitro down-regulation) or that the mechanisms of fibronectin mRNA degradation were up-regulated by the artificial context of in vitro culture. Whatever the actual mechanism, it is clear that fibronectin gene expression in mononuclear phagocytes did not appear to follow the patterns established for many other mononuclear phagocyte mediators.

\section{Acknowledgments}

We would like to thank J. Schmidt and M. Tocci, Merck Sharp and Dohme Research Laboratories, for the use of the IL-1 $\beta$ probe.

\section{References}

1. Ruoslahti, E., E. Engvall, and E. G. Hayman. 1981. Fibronectin: current concepts of its structure and functions. Collagen Relat. Res. 1:95-128.

2. Hynes, R. O., and K. M. Yamada. 1982. Fibronectins: multifunctional modular glycoproteins. J. Cell Biol. 95:369-377.

3. Furcht, L. T. 1983. Structure and function of the adhesive glycoprotein fibronectin. Mod. Cell Biol. 1:53-117.

4. Yamada, K. M. 1983. Cell surface interactions with extracellular materials. Annu. Rev. Biochem. 52:761-799.

5. Mosher, D. F. 1984. Physiology of fibronectin. Annu. Rev. Med. 35:561-575.

6. Villiger, B., D. G. Kelley, W. Engleman, C. Kuhn, and J. A. McDonald. 1981. Human alveolar macrophage fibronectin synthesis, secretion, and ultrastructural localization during gelatin-latex particles binding. J. Cell Biol. 90:711-720.

7. Rennard, S. I., G. W. Hunninghake, P. B. Bitterman, and R. G. Crystal. 1981. Production of fibronectin by the human alveolar macrophage: mechanism for the recruitment of fibroblasts to sites of tissue injury in interstitial lung diseases. Proc. Natl. Acad. Sci. USA. 78:7147-7151.

8. Villiger, B. 1983. Function of pulmonary alveolar macrophage fibronectin. Curr. Prob. Clin. Biochem. 13:190-201.

9. Rennard, S. I., and R. G. Crystal. 1981. Fibronectin in human bronchopulmonary lavage fluid. Elevation in patients with interstitial lung disease. J. Clin. Invest. 69:113-122.

10. Villiger, B., G. J. Heymach, T. J. Broekelmann, D. G. Kelley, C. Kuhn, and J. A. McDonald. 1982. Human bronchoalveolar fibronectin: quantification of an opsonic protein and its synthesis by alveolar macrophages. Chest. 81:45S-47S.

11. Villiger, B., T. J. Broekelmann, D. G. Kelley, G. J. Heymach, and J. A. McDonald. 1981. Bronchoalveolar fibronectin in smokers and nonsmokers. Am. Rev. Respir. Dis. 124:652-654.

12. Bitterman, P. B., S. I. Rennard, S. Adelberg, and R. G. Crystal. 1983. Role of fibronectin as a growth factor for fibroblasts. J. Cell Biol. 97:1925-1932.

13. Davis, W. B., S. I. Rennard, P. B. Bitterman, and R. G. Crystal. 1983. Pulmonary oxygen toxicity: early reversible changes in human alveolar structures induced by hyperoxia. N. Engl. J. Med. 309:879883.

14. Torikata, C., B. Villiger, C. Kuhn, and J. A. McDonald. 1985. Ultrastructural distribution of fibronectin in normal and fibrotic human lung. Lab. Invest. 52:399-408.

15. Crystal, R. G., J. D. Fulmer, W. C. Roberts, M. L. Moss, B. R. Line, and H. Y. Reynolds. 1976. Idiopathic pulmonary fibrosis: clinical, histologic, radiographic, physiologic, scintigraphic, cytologic, and biochemical aspects. Ann. Intern. Med. 85:769-788.

16. Fulmer, J. D., W. C. Roberts, E. R. von Gal, and R. G. Crystal. 
1979. Morphologic-physiologic correlates of the severity of fibrosis and degree of cellularity in idiopathic pulmonary fibrosis. J. Clin. Invest. 63:665-676.

17. Bøyum, A. 1976. Isolation of lymphocytes, granulocytes and macrophages. Scand. J. Immunol. 5(Suppl. 5):9-15.

18. Tucker, S. B., R. V. Pierre, and R. E. Jordon. 1977. Rapid identification of monocytes in a mixed mononuclear cell preparation. J. Immunol. Methods. 14:267-269.

19. Reynolds, H. Y., J. D. Fulmer, J. A. Kazmierowski, W. C. Roberts, M. M. Frank, and R. G. Crystal. 1977. Analysis of cellular and protein content of broncho-alveolar lavage fluid from patients with idiopathic pulmonary fibrosis and chronic hypersensitivity pneumonitis. J. Clin. Invest. 59:165-175.

20. Rennard, S. I., G. R. Martin, and R. G. Crystal. 1982. Enzyme linked immunoassay (ELISA) for connective tissue proteins: type I collagen. In Immunochemistry of the Extracellular Matrix. Vol. 1. H. Furthmayer, editor. CRC Press, Boca Raton, FL. 237-252.

21. Chirgwin, J. M., A. E. Przybyla, R. J. MacDonald, and W. J. Rutter. 1979. Isolation of biologically active ribonucleic acid from sources enriched in ribonuclease. Biochemistry. 18:5294-5299.

22. Thomas, P. S. 1980. Hybridization of denatured RNA and small DNA fragments transferred to nitrocellulose. Proc. Natl. Acad. Sci. USA. 77:5201-5205.

23. Bernard, M. P., M. Kolbe, D. Weil, and M.-L. Chu. 1985. Human cellular fibronectin: comparison of the carboxyl-terminal portion with rat identifies primary structural domains separated by hypervariable regions. Biochemistry. 24:2698-2704.

24. Gunning, P., P. Ponte, H. Okayama, J. Engel, H. Blau, and L. Kedes. 1983. Isolation and characterization of full-length cDNA clones for human $\alpha$-, $\beta$-, and $\gamma$-actin mRNAs: skeletal but not cytoplasmic actins have an amino-terminal cysteine that is subsequently removed. Mol. Cell. Biol. 3:787-795.

25. Miskulin, M., R. Dalgleish, B. Kluve-Beckerman, S. I. Rennard, P. Tolstoshev, M. Brantly, and R. G. Crystal. 1986. Human type III collagen gene expression is coordinately modulated with the type I collagen genes during fibroblast growth. Biochemistry. 25:1408-1413.

26. Tocci, M. J., N. I. Hutchinson, P. M. Cameron, K. E. Kirk, D. J. Norman, J. Chin, E. A. Rupp, G. A. Limjuco, V. M. Bonilla-Argudo, and J. A. Schmidt. 1987. Expression in Escherichia coli of free active recombinant human IL- $1 \beta$, comparison with native human

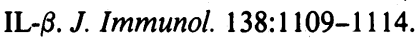

27. Anchors, J. M., R. G. Gregg, S. W. Law, and H. B. Brewer. 1986. ApoE deficiency: markedly decreased levels of cellular ApoE mRNA. Biochem. Biophys. Res. Commun. 134:937-943.

28. Meinkoth, J., and G. Wahl. 1984. Hybridization of nucleic acids immobilized on solid supports. Anal. Biochem. 138:267-284.

29. Mornex, J.-F., A. Chytil-Weir, Y. Martinet, M. Courtney, J.-P. LeCocq, and R. G. Crystal. 1986. Expression of the alpha-1-antitrypsin gene in mononuclear phagocytes of normal and alpha-1-antitrypsindeficient individuals. J. Clin. Invest. 77:1952-1961.

30. Martinet, Y., P. B. Bitterman, J.-F. Mornex, G. R. Grotendorst, G. R. Martin, and R. G. Crystal. 1986. Activated human monocytes express the c-sis proto-oncogene and release a mediator showing PDGF-like activity. Nature (Lond.). 319:158-160.

31. Mosesson, M. W., and R. A. Umfleet. 1970. The cold-insoluble globulin of human plasma. I. Purification, primary characterization, and relationship to fibrinogen and other cold-insoluble reaction components. J. Biol. Chem. 245:5728-5736.

32. Mosher, D. F. 1975. Cross-linking of cold-insoluble globulin by fibrin-stabilizing factor. J. Biol. Chem. 250:6614-6621.

33. Johansson, S., K. Rubin, M. Höök, T. Ahlgren, and R. Seljelid. 1979. In vitro biosynthesis of cold insoluble globulin (fibronectin) by mouse peritoneal macrophages. FEBS (Fed. Eur. Biochem. Soc.) Lett. 105:313-316.

34. Alitalo, K., T. Hovi, and A. Vaheri: 1980. Fibronectin is produced by human macrophages. J. Exp. Med. 151:602-613.

35. Tsukamoto, Y., W. E. Helsel, and S. M. Wahl. 1981. Macro- phage production of fibronectin, a chemoattractant for fibroblasts. $J$. Immunol. 127:673-678.

36. Cofano, F., P. M. Comoglio, S. Landolfo, and G. Tarone. 1984. Mouse immune interferon enhances fibronectin production of elicited macrophages. J. Immunol. 133:3102-3106.

37. Gerdes, J. S., S. D. Douglas, G. B. Kolski, M. C. Yoder, and R. A. Polin. 1984. Decreased fibronectin biosynthesis by human cord blood mononuclear phagocytes in vitro. J. Leukocyte Biol. 35:91-99.

38. Goldstein, C. S., R. E. Garrick, R. A. Polin, J. S. Gerdes, G. B. Kolski, E. G. Neilson, and S. D. Douglas. 1986. Fibronectin and complement secretion by monocytes and peritoneal macrophages in vitro from patients undergoing continuous ambulatory peritoneal dialysis. J. Leukocyte Biol. 39:457-464.

39. Mononuclear phagocytes: functional aspects of mononuclear phagocytes. 1980. R. Van Furth, editor. Nijhoff, Boston.

40. Snyderman, R., and S. E. Mergenhagen. 1976. Chemotaxis of macrophages. In Immunobiology of the Macrophage. D. S. Nelson, editor. Academic Press, New York. 323-346.

41. Leibovich, S. J., and R. Ross. 1975. The role of the macrophage in wound repair. A study with hydrocortisone and antimacrophage serum. Am. J. Pathol. 78:71-100.

42. Hynes, R. 1985. Molecular biology of fibronectin. Annu. Rev. Cell Biol. 1:67-90.

43. Kornblihtt, A. R., K. Vibe-Pedersen, and F. E. Baralle. 1983. Isolation and characterization of cDNA clones for human and bovine fibronectins. Proc. Natl. Acad. Sci. USA. 80:3218-3222.

44. Tamkun, J. W., J. E. Schwarzbauer, and R. O. Hynes. 1984. A single rat fibronectin gene generates three different mRNAs by alternative splicing of a complex exon. Proc. Natl. Acad. Sci. USA. 81:5140-5144.

45. Schwarzbauer, J. E., J. W. Tamkun, I. R. Lemischka, and R. O. Hynes. 1983. Three different fibronectin mRNAs arise by alternative splicing within the coding region. Cell. 35:421-431.

46. Hynes, R. O., J. E. Schwarzbauer, and J. W. Tamkun. 1984. Fibronectin: a versatile gene for a versatile protein. CIBA Found. Symp. 108:75-92.

47. Kornblihtt, A. R., K. Vibe-Pedersen, and F. E. Baralle. 1984. Human fibronectin: molecular cloning evidence for two mRNA species differing by an internal segment coding for a structural domain. EMBO (Eur. Mol. Biol. Organ.) J. 3:221-226.

48. Kornblihtt, A. R., K. Vibe-Pedersen, and F. E. Baralle. 1984. Human fibronectin: cell specific alternative mRNA splicing generates polypeptide chains differing in the number of internal repeats. Nucleic Acids Res. 12:5853-5868.

49. Vibe-Pedersen, K., A. R. Kornblihtt, and F. E. Baralle. 1984. Expression of a human $\alpha$-globin/fibronectin gene hybrid generates two mRNAs by alternative splicing. EMBO (Eur. Mol. Biol. Organ.) J. 3:2511-2516.

50. Schwarzbauer, J. E., J. I. Paul, and R. O. Hynes. 1985. On the origin of species of fibronectin. Proc. Natl. Acad. Sci. USA. 82:14241428.

51. Umezawa, K., A. R. Kornblihtt, and F. E. Baralle. 1985. Isolation and characterization of CDNA clones for human liver fibronectin. FEBS (Fed. Eur. Biochem. Soc.) Lett. 186:31-34.

52. Kornblihtt, A. R., K. Umezawa, K. Vibe-Pedersen, and F. E. Baralle. 1985. Primary structure of human fibronectin: differential splicing may generate at least 10 polypeptides from a single gene. EMBO (Eur. Mol. Biol. Organ.) J. 4:1755-1759.

53. Paul, J. I., J. E. Schwarzbauer, J. W. Tamkun, and R. O. Hynes. 1986. Cell-type-specific fibronectin subunits generated by alternative splicing. J. Biol. Chem. 261:12258-12265.

54. Oldberg, A., and E. Ruoslahti. 1986. Evolution of the fibronectin gene. Exon structure of cell attachment domain. J. Biol. Chem. 261:2113-2116.

55. Sekiguchi, K., A. M. Klos, K. Kurachi, S. Yoshitake, and S.-I. Hakomori. 1986. Human liver fibronectin complementary DNAs: 
identification of two different messenger RNAs possibly encoding the $\alpha$ and $\beta$ subunits of plasma fibronectin. Biochemistry. 25:4936-4941.

56. Gutman, A., K. M. Yamada, and A. Kornblihtt. 1986. Human fibronectin is synthesized as a pre-propolypeptide. FEBS (Fed. Eur. Biochem. Soc.) Lett. 207:145-148.

57. Vibe-Pedersen, K., S. Magnusson, and F. E. Baralle. 1986. Donor and acceptor splice signals within an exon of the human fibronectin gene: a new type of differential splicing. FEBS (Fed. Eur. Biochem. Soc.) Lett. 207:287-291.

58. Raghow, R., S. Lurie, J. M. Seyer, and A. H. Kang. 1985 Profiles of steady state levels of messenger RNAs coding for type I procollagen, elastin, and fibronectin in hamster lungs undergoing bleomycin-induced interstitial pulmonary fibrosis. J. Clin. Invest. 76:1733-1739.

59. Tyagi, J. S., H. Hirano, G. T. Merlino, and I. Pastan. 1983. Transcriptional control of the fibronectin gene in chick embryo fibroblasts transformed by Rous sarcoma virus. J. Biol. Chem. 258:57875793.

60. Nathan, C. F., H. W. Murray, and Z. A. Cohn. 1980. The macrophage as an effector cell. N. Engl. J. Med. 303:622-626.

61. Takemura, R., and Z. Werb. 1984. Secretory products of macrophages and their physiological functions. Am. J. Physiol. 246(Suppl.):C1-C9. 